\title{
Stimulus-response time to alarms of the intra-aortic balloon pump: safe care practices
}

\author{
Tempo estímulo-resposta aos alarmes do balão intraórtico: práticas para cuidado seguro \\ El tempo estíulo-respuesta de las alarmas del balón de contrapulsación intraaórtico: \\ prácticas para el cuidado seguro
}

\begin{abstract}
Andrezza Serpa Franco', Adriana Carla Bridi', Monica de Almeida Karam", Ana Paula Amorim Moreira', Karla Biancha Silva de Andrade'II, Roberto Carlos Lyra da Silva'

' Universidade Federal do Estado do Rio de Janeiro, School of Nursing, Postgraduate Program in Nursing and Biosciences. Rio de Janeiro, Brazil. "Universidade Federal do Estado do Rio de Janeiro, School of Nursing, Postgraduate Program in Nursing. Rio de Janeiro, Brazil.

III Universidade do Estado do Rio de Janeiro, School of Nursing. Rio de Janeiro, Brazil.
\end{abstract}

How to cite this article:

Franco AS, Bridi AC, Karam MA, Moreira APA, Andrade KBS, Silva RCL. Stimulus-response time to alarms of the intra-aortic balloon pump: safe care practices. Rev Bras Enferm [Internet]. 2017;70(6):1206-11. DOI: http://dx.doi.org/10.1590/0034-7167-2016-0432

Submitssion: 09-10-2016

Approval: 02-05-2017

\section{ABSTRACT}

Objective: To characterize the sound alarms of the Intra-Aortic Balloon Pump (IABP) during aortic counterpulsation therapy; to measure the stimulus-response time of the team to these; and to discuss the implications of increasing this time for patient safety from the alarm fatigue perspective. Method: This is an observational and descriptive study with quantitative and qualitative approach, case study type, carried out in a Cardiac Surgical Intensive Care Unit. Results: The most audible IABP alarm was the one of high priority increased-reduced diastolic blood pressure. The stimulus-response time was 33.9 seconds on average. Conclusion: Managing the alarms of these equipment is essential to minimize the occurrence of the alarm fatigue phenomenon and to offer a safer assistance to patients who rely on this technology.

Descriptors: Critical Care; Monitoring; Clinical Alarms; Near Miss; Patient Safety.

\section{RESUMO}

Objetivo: Caracterizar os alarmes sonoros disparados pelo balão intra-aórtico (BIA) durante a terapia de contrapulsação aórtica; medir o tempo estímulo-resposta da equipe a esses e discutir as implicações do alargamento desse tempo para a segurança do paciente na perspectiva da fadiga de alarmes. Método: Trata-se de um estudo descritivo observacional, com abordagem quantiqualitativa, do tipo estudo de caso, realizado em uma Unidade de Terapia Cardiointensiva Cirúrgica. Resultados: O alarme sonoro mais disparado pelo BIA foi o de pressão diastólica aumentada-diminuída, de alta prioridade. O tempo estímulo-resposta foi em média de 33,9 segundos. Conclusão: O gerenciamento dos alarmes desses equipamentos torna-se imprescindível para minimizar a ocorrência do fenômeno fadiga de alarmes e na oferta de uma assistência mais segura ao paciente dependente dessa tecnologia. Descritores: Terapia Intensiva; Monitorização; Alarmes Clínicos; Near Miss; Segurança do Paciente.

\section{RESUMEN}

Objetivo: Caracterizar las alarmas sonoras disparadas por el balón de contrapulsación intraaórtico (BCIA) durante la terapia de contrapulsación aórtica; calcular el tiempo estímulo-respuesta del dispositivo y discutir las implicaciones al extenderse el tiempo para la seguridad del paciente cuando presente fatiga por las alarmas. Método: Estudio descriptivo observacional, con enfoques cuantitativo y cualitativo, de tipo estudio de caso, Ilevado a cabo en una Unidad de Cuidado Cardiontensivo Quirúrgico. Resultados: La alarma sonora más disparada por el BClA fue la de la diástole aumentada y disminuida, de alta necesidad. El promedio del tiempo estímulo-respuesta fue de 33,9 segundos. Conclusión: La gestión 
de las alarmas de este dispositivo se hace imprescindible para minimizar su fatiga a los pacientes que lo utilizan y para ofrecerles un cuidado más seguro.

Descriptores: Cuidados Críticos; Monitoreo; Alarmas Clínicas; Near Miss; Seguridad del Paciente.

\section{CORRESPNDING AUTHOR Andrezza Serpa Franco E-mail: dezza.franco@gmail.com}

\section{INTRODUCTION}

The Intra-Aortic Balloon Pump (IABP) was clinically introduced in the 1960s as a cardiogenic shock therapy after Myocardial Infarction (MI). Another group of patients who benefit from the IABP therapy is the one with drug therapy-resistant unstable angina ${ }^{(1)}$.

Counterpulsation by an intra-aortic balloon pump is a circulatory assistance method performed by a mechanical support for patients with circulatory and heart failure, and it is responsible for increasing myocardial perfusion satisfactorily through a synchronic mechanism. The appropriate programming requires the coordination of inflation and deflation of the balloon with the patient's cardiac cycle, which occurs by the pressurization of the helium that is conditioned in the IABP console ${ }^{(1)}$.

Currently, the machine console used for cycling of the intraaortic balloon pump is equipped with a system of clinical alarms; the asynchronism alarm is an example. When it sets off, it alerts the professional about a possible lack of synchronism, putting the patient's life at risk. The lack of synchronism may result in a decrease in myocardial perfusion and, consequently, in the increased probability of fatal arrhythmias, such as: ventricular fibrillation, ventricular tachycardia and acute coronary syndrome ${ }^{(2)}$.

The concern with the safety of critical patients has been subject of study of many researchers around the world. However, the concern with problems related to misuse of alarm systems of assistance medical equipment (AME) in intensive care, when compared with those related to administration of medicines, for example, is still something very incipient, especially in Brazil(3).

Although professionals in intensive care units may be concerned with issues related to patient safety, it seems they still fail to realize how important alarm systems are. Despite the technological advances in the health care area, specifically regarding alarm systems of life advanced support equipment, currently, there are discussions whether they really are a good alert in intensive care units (ICU), considering the problems related to the misuse of this resource ${ }^{(4)}$.

In this perspective, the stimulus-response time of professionals to the alarm ring becomes imperious for a proper case management and for a favorable and positive outcome for patients. In this study, the stimulus-response time of the team to the sound alarms of the intra-aortic balloon pump is understood as the time between the alarm ring and the intervention of the health professional next to the bed, whatever it may be.

This question seems to gain more support in light of recent publications dealing with the patient safety topic and alluding to the abusive use of alarms. Since 2011, the Emergency Care Research Institute (ECRI - Pennsylvania - USA), a non-profit organization that researches best practices for medical procedures, equipment, medicines and other procedures, published a list that points alarms as the main threat of technologies to patient safety.
Through its authors, the institution claims that the alarm may not only be a tool for safety assurance, and that it is important to reflect on risks related to alarm rings when they are not prioritized as they should $\mathrm{be}^{(5)}$. In this sense, scholars and researchers warn of a phenomenon that incites an even bigger concern: alarm fatigue ${ }^{(6)}$.

Alarm fatigue is defined as the phenomenon that occurs when a very large number of alarms covers the clinically significant ones, enabling alarms of clinical relevance to be disabled, silenced and ignored by the team ${ }^{(7)}$. This concept makes us reflect on the need to improve the audibility of clinical alarms in an Intensive Care Unit, which is why noise reduction in the unit becomes imperious.

The term "alarm fatigue" was created to describe a reduction in clinical sensibility to alarm systems, which, as a consequence, compromises monitoring safety and assistance for patients. Therefore, we emphasize the need for improvement in the alarm systems of the current monitors, reminding once again that team work adherence is essential in all stages of the process ${ }^{(3,5,7)}$.

Alarms are designed to alert professionals about possible clinical changes on patients, as well as to warn them about technical problems of the equipment. In this sense, alarms are necessary tools to signal potential threats to patient safety.

On the other hand, rings of false alarms by the equipment may cover up the alarms that are in fact relevant, and they must be investigated by the professionals. Considering the relevance of the topic to patient safety, the following research problem came up: What is the stimulus-response time of health professionals to the IABP alarms and what are the implications for patient safety in this context?

From this question, we set up the following objectives: 1) to characterize the sound alarms set off by the Intra-Aortic Balloon Pump (IABP) during the aortic counterpulsation therapy; 2) to measure the stimulus-response time of the team to these alarms; 3) to discuss the implications of increasing this stimulus-response time for patient safety from the alarm fatigue perspective.

\section{METHOD}

\section{Ethical aspects}

This research was approved by the Research Ethics Committee of the hospital in December 11, 2013.

\section{Study design, location and period}

This is a quantitative, qualitative and descriptive study, case study type. We chose this design and approach for believing the objective of the study could only be reached with a research of observation and description of the phenomenon in its locus, giving voice to the subjects who experience it, since to understand the "alarm fatigue" phenomenon, we needed more deepening and reflection.

For this study, we understand that the quantitative and qualitative approach is complementary. Descriptive statistics can enlighten 
the reader to establish a relationship with the real theoretical world and the proposed theoretical world, by offering a deductive scope. Qualitative research offers us a possibility to investigate uniformity, regularities or non-regularities in human behavior. Therefore, we believe the fact, and we will analyze the time of the alarms as a mathematical variable; it would be an isolated datum if we did not include human behavior in the alarm setting off situation. The quantitative and qualitative method will allow a better conduction of our results.

The research scenario was the cardiac surgery postoperative unit of a large federal hospital specialized in cardiology.

Data collection occurred from December 2013 to April 2014, through direct observation by using a data collection instrument. Sixty hours of observation were carried out in a discontinuing way, covering diurnal and nocturnal services of the consoles/machines used in aortic counterpulsation therapy (IABP) in hospitalized patients. Data were presented in graphs, after being treated on Microsoft Office Excel ${ }^{\circledR} 2010$.

\section{Population, inclusion and exclusion criteria}

The participants of the research were doctors and nurses who work at the unit, since these professionals deal with this technology. Subjects excluded of the study were those who are not part of the direct assistance to these patients and may be at the unit as medical examiners, physician assistants, vascular doctors, echocardiographers, nephrologists, and others who do not belong to the referred unit, such as physical therapists, nursing assistants and nursing technicians, for not dealing with the intra-aortic balloon pump, as well as health professionals during leaves or transferred from the Cardiac Surgical Intensive Care Unit, and professionals who did not accept to participate in the research.

\section{Study protocol}

Each alarm was measured with digital chronometers model CD-2800, countdown type. The chronometer was started every time the alarm rang, which was interrupted when the alarm was answered or when it exceeded five minutes. This time was defined by the fact that, in the case of a heart arrest (HA), an absolute common emergency among critical patients, answers to the alarms must be fast, since cardiopulmonary resuscitation maneuvers must be performed immediately to avoid worse neurological outcomes for patients, decreasing their survival rate.

\section{RESULTS}

Thirty-two alarms of the intra-aortic balloon pump were registered during 60 hours of observation. Out of these, fifteen obtained a response of the professionals in the bedside and the other seventeen alarms that rang were automatically silenced, without any professional intervention, and for that reason, they were considered lost alarms. We used descriptive statistics, using the mean for time of the alarms that the intra-aortic balloon pump set off.

All alarms silenced automatically, even before the professional had come for it, given its short time, were considered lost. Out of the 15 alarms answered by health professionals, 11 were answered by nurses and 4 by doctors.
Regarding the reasons why the alarms rang, 24 rang due to decreased high diastolic blood pressure (HDBP), 4 due to signal interference, 3 because there was no ring signal and 1 for lack of helium gas.

One of the objectives of this technology is increasing high diastolic blood pressure (HDBP). When the therapy objective is not achieved, an alarm called Decreased High Diastolic Blood Pressure is set off. The value is considered ideal when the peak of the increased diastolic pressure is at least equal to the previous systolic pressure peak ${ }^{(1)}$.

Therefore, in this case, the alarm that rang the most was for decreased HDBP, which is considered a high priority alarm by the manufacturer for indicating a situation that requires an immediate response from the operator. In addition, it is one of the main parameters to indicate whether the aortic counterpulsation therapy is providing a satisfactory gain for the patient or not.

Regarding the response time to the alarms of the intra-aortic balloon pump, it was possible to consider that they were satisfactorily answered, in the mean time of 33.9 seconds, within the expected limit (not lower than five minutes). The alarms that were silenced automatically totalized a mean of 40.2 seconds.

\section{Number of alarms set off by the intra-aortic balloon pump}

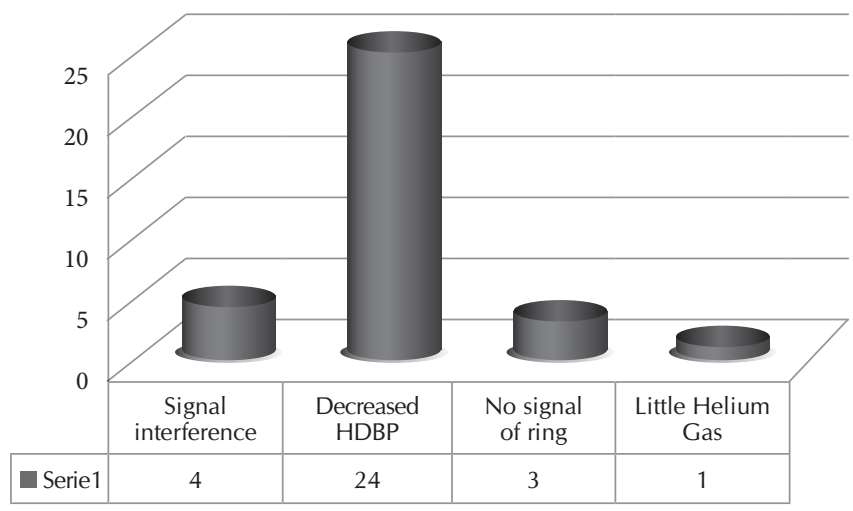

Note: HDBP- High Diastolic Blood Pressure

Figure 1 - Characteristic of the alarms set off by the intra-aortic balloon pump

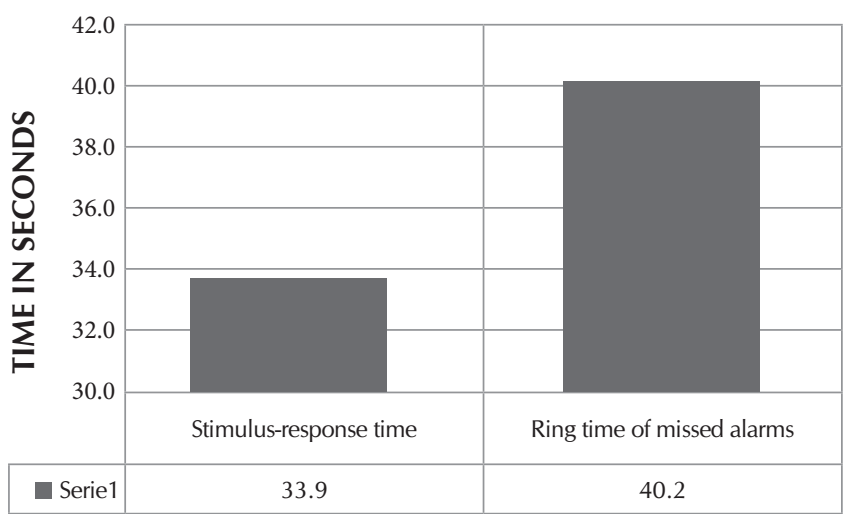

Figure 2 - Stimulus-response time to alarms of the intra-aortic balloon pump and ring time of missed alarms in seconds 
A datum of this study that caught our attention was the professional category that answers to the IABP alarm. Among the fifteen alarms answered, the largest number $(n=11)$ was answered by nurses. No alarm was answered by physical therapists or nursing technicians.

In a recent study, the author points the determining factors that led nursing professionals to answer multiparametric monitors and concluded that nurses prioritize their response based on the seriousness of the patient's condition and on the hemodynamic support use, since they see in these patients a higher probability of physiological changes and need for immediate interventions ${ }^{(8)}$, which may corroborate the largest number of alarms answered by nurses during the aortic counterpulsation with IABP.

The fact that most alarms $(n=11)$ were answered by nurses led us to understand that identifying urgency of the alarm contributes to the answer of nurses to the alarm and that these professionals use additional strategies to determine their answers, including criticality of the patient, signal duration, alarm parameter and workload ${ }^{(7)}$.

\section{DISCUSSION}

It was interesting to notice that the behavior of professionals of the team towards the alarms set off by the intra-aortic balloon pump console proved to be quite different from the reality measured in other studies, which also assessed alarm fatigue of assistance medical equipment, including international studies ${ }^{(9-10)}$.

The study by Bridi highlighted that alarms set off by multiparametric monitors in a coronary care unit were mostly answered by nursing technicians, with $60 \%$ alarm fatigue, that is, answered with extended time, leaving patients vulnerable.

The stimulus-response time of the team to the alarms of the intra-aortic balloon pump console was considerably lower than those measured with multiparametric monitor, mechanical ventilator and pulse oximetry, reported in the studies. This was a pleasant surprise, despite knowing this was the first study on alarm fatigue of intra-aortic balloon pump consoles.

Another fact that can contribute to the understanding of the data found considering the response time of nurses to alarms of the intra-aortic balloon pump is that the studied unit has a personnel sizing (3.8 patient/nurse ratio) very close to the patient/nurse ratio determined by the Ordinance 123 of the Ministry of Health, from February 28, 2005, for meeting high complexity services of Postoperative Cardiac Surgery, which establishes 1 nurse/3 beds ${ }^{(11)}$.

In addition, COFEN Resolution no. 293/2004 establishes parameters for sizing the nursing personnel in the service units of health institutions and alike, destining $52 \%$ to $56 \%$ nurses and nursing technicians for intensive care ${ }^{(12)}$.

These data lead us to reflect on the need to emphasize the importance of nurses in the direct care to critical patients, which is regulated by law lo. 7.498/86. Article 11 of this law gives nurses the exercise of all nursing activities, which include direct nursing care for critical patients with life risk and nursing care of higher technical complexity that requires scientifically-based knowledge and ability to make immediate decisions ${ }^{(13)}$.
Considering alarms of monitored variable by the IABP console, the fact that alarms related to decreased HDBP were the variable that most caused alarm signals caught our attention, since it is a high priority alarm that tries to alert the professional for myocardial oxygenation issues in patients who need immediate intervention.

Delay to answer the decreased HDBP alarm may directly compromise patient safety. The high priority alarms of the intra-aortic balloon pump may interrupt therapy and reduce pressure on the aortic root, which compromises a better coronary perfusion, making the patient vulnerable to a myocardial ischemia and to the occurrence of a possible adverse event.

The alarms rang because the increased diastolic pressure was below the allowed limit, when the patient presents pressure instability, such as hypotension. When the team observed this event, some of them adjusted the decreased HDBP parameter to values way below of the expected. At that moment, we argued if therapy was really recommended, since there was no increased pressure on the aortic root; consequently, the objective of the balloon for those patients would not be achieved in the programmed therapy.

Despite possible interventions aimed at reducing adverse events, patient safety and quality of care form a complex binomial that depends on participation of all members of the production chain of health services.

It is necessary to analyze and consider that the IABP is not a routine equipment and that its sounds significantly differ from others, which increases the alert state of professionals. This may be directly related to the fact that stimulus-response time to these alarms were answered within safe limits (33.9 seconds), less than five minutes, helping to minimize adverse events caused by alarm fatigue or false alarms.

Postoperative patient specificity, along with differentiated alarms set off by the IABP, training taken by the team, use of protocols and the fact that critical patient care belongs exclusively to nurses, are factors that can contribute to assistance time within the limits of patient safety regarding delay (in this study, less than a minute). This is crucial in the heart arrest case, if we consider the guidelines to initiate cardiopulmonary resuscitation maneuvers, which must take less than five minutes, mainly in heart arrest modalities caused by Ventricular Fibrillation (VF), Pulseless Ventricular Tachycardia (PVT), Pulseless Electrical Activity (PEA) rhythms and Asystole ${ }^{(9-10,14-15)}$.

On the other hand, still about heart arrest cases, if we consider that every one minute of delay to answer the alarms, there is a worse risk for patients, the ring time of lost alarms (40.2 seconds) previously conceptualized, although it was less than a minute, it may compete with the relevant alarms set off by the IABP, contributing to a false urgency feeling. In addition, this datum could denote a possible inadequate parameterization of the IABP. We have not found similar studies related to the IABP. Therefore, we cannot make any comparisons or allusions at this time.

Distorting the threshold values of alarms (for more and for less) can result in frequent violations. If the threshold values are set well below the basal condition of the patient, this generates a large number of set off alarms, or may even result in loss of events, when the threshold values are set well above 
the basal condition of the patient. Both cases compete for alarm fatigue and put patient safety at risk ${ }^{(6,9)}$.

In this sense, the proper programming of alarms to the individual needs of patients has to be immediately incorporated into the routine of nursing. Alarms, when not properly adjusted, when switched off or when with high volume, can lead to serious adverse events, to the extent that major events can be missed ${ }^{(9,16-17)}$.

The alarm parameterization of the physiological variables monitored by AME need, therefore, to be registered by the nursing staff and other team members in the patient record, and this must occur every time the limits are changed, in such a way that the whole team can take notice. We believe that in doing so we will be using the alarm data as a precious source of clinical information about patient condition. It is worrisome to think that the alarms that were designed to protect patients have, instead, led to an insecurity increase in the intensive care units.

\section{Study limitations}

We can consider as difficulty and limitation of the study the knowledge by the unit's health team of the presence of the researcher in the days when a patient was using the IABP. We believe that the professionals may have increased surveillance on the IABP in the presence of the researcher.

\section{Contributions to the nursing field}

This study aims to contribute to the reflection on the management of clinical alarms in the health units, especially in units with severely ill patients. Through the management of clinical alarms, we can minimize this false sense of safety that has currently been present in these units by the lack of alarms.

\section{CONCLUSION}

During the 60 hours of observation, the involvement of nurses and doctors in the care to patients with use of IABP therapy regarding alarms was clear. The results found in this study further reinforce the understanding that the assistance medical equipment used both in the monitoring and support in intensive care units are machines that also require care, since they often play vital roles, as an extension of a body that, for now, is not able, by itself, to achieve the much needed homeostasis.

From this perspective, the electromedical equipment increasingly require that nurses act to the bedside of the patient who benefits from these technologies, seeing this activity as unique to this professional category, by the results with stimulus-response time to the satisfaction and within the safety threshold.

Regarding the alarms of monitored variable by the IABP console, the fact that alarms related to decreased HDBP was the variable that most caused alarm signals caught our attention, since it is a high priority alarm that tries to alert the professional for myocardial oxygenation issues in patients who need immediate intervention. Delay in answering the decreased HDBP alarm may directly compromise patient safety. The high priority alarms of the intra-aortic balloon pump can cease therapy. Before this event, the low pressure on the aortic root may compromise a better coronary perfusion, making the patient vulnerable to a myocardial ischemia and to the occurrence of a possible adverse event. Despite possible interventions aimed at reducing adverse events, patient safety and quality of care form a complex binomial that depends on participation of all members of the production chain of health services.

Although these alarms have been answered in less than a minute, the amount of missed alarms (those who are automatically silenced, regardless of any professional intervention) was a concern, which could denote a possible inadequate parameterization.

Distorting the threshold values of alarms (for more and for less) may result in frequent violations. If the threshold values are set well below the basal condition of the patient, this generates a large number of set off alarms, or may even result in loss of events, when the threshold values are set well above the basal condition of the patient. Both cases compete for alarm fatigue and put patient safety at risk. The proper programming of alarms to the individual needs of patients has to be immediately incorporated into the routine of nursing. Alarms, when not properly adjusted, when switched off or when with high volume, may lead to serious adverse events, to the extent that major events can be missed.

The alarm parameterization of the physiological variables monitored by AME need, therefore, to be registered by the nursing staff and other team members in the patient record, and this must occur every time the limits are changed, so that the whole team can take notice. We believe that in doing so we will be using the alarm data as a precious source of clinical information about the patient condition. It is worrisome to think that the alarms that were designed to protect patients have, instead, led to an insecurity increase in the intensive care units. Through the management of clinical alarms, we believe that we can minimize this false sense of safety that has currently been present in these units by the lack of alarms.

Thus, based on the results found and from the perspective of intensive care, this study leads us to the reflection and understanding on the importance of alarm management, focusing on parameterization, and on increasing surveillance in order to monitor. The emphasis on better use of the information, in a rational and intelligent way, of the technological resources and AME alarm systems may contribute to the optimization of surveillance and safety in intensive care, minimizing the risks of an incident with damage or adverse event.

\section{REFERENCES}

1. Woods SL, Froelicher ESS, Motzer SU. Enfermagem em cardiologia. 4. ed. São Paulo: Manole; 2005.

2. Sociedade Brasileira de Cardiologia. Diretriz brasileira de insuficiência cardíaca aguda 2009. Arq Bras Cardiol[Internet]. 2012[cited 2015 Oct 21];(93):1-65 Available from: http://www.arquivosonline.com.br/2012/9805/pdf/9805001.pdf 
3. Silva RCL, Pergher AK. Fadiga de alarmes: uma revisão integrativa. Rev Enferm UFPE[Internet]. 2013[cited 2015 Oct 21];(7):12417. Available from: http://www.revista.ufpe.br/revistaenfermagem/index.php/revista/article/view/3589

4. Silva MJP, Araújo MMT, Puggina AC. Humanização em UTI. IN: Padilha KG,Vattimo WFF,Silva SC, Kimura M. Enfermagem em UTI: cuidando do paciente crítico: Barueri,SP: Manole; 2010. p. 1355.

5. Emergency Care Research Institute. (ECRI). Health Device: top 10 health technology hazards for 2015 [Internet]. 2015 [cited 2016 Mar 30]. Available from: https://www.ecri.org/Documents/White_papers/Top_10_2015.pdfl

6. Siebig S, kuhls S, Imhoff M, Gather U, Schölmerich J, et al. Intensive care unit alarms: how many do we need? Crit Care Med[Internet]. 2010 [cited 2016 Mar 30];(38):451-6. Available from: http://www.ncbi.nlm.nih.gov/pmc/articles/PMC4309240/

7. Cvach M. Monitor alarm fatigue: an integrative review. biomedical instrumental technology. 2012 [cited 2016 Mar 30];(46):26877. Available from: http://www.aami-bit.org/doi/pdf/10.2345/0899-8205-46.4.268

8. Bridi AC. Fatores determinantes do tempo estímulo-resposta da equipe de enfermagem aos alarmes dos monitores multiparamétricos em terapia intensiva: implicações para segurança do paciente grave. Rio de Janeiro. [Dissertação]. Universidade Federal do Estado do Rio de Janeiro; 2013.

9. Vanheusden LMS, Santoro DC, Szpilman D, Batista CO ,Correia LFB, et al. Conceito fase-dependente na ressuscitação cardiopulmonar. Rev Soc Cardiol[Internet]. 2007 [cited 2016 Mar 30];(20):60-64. Available from: http://sociedades.cardiol.br/ socerj/revista/2007_01/a2007_v20_n01_art09.pdf

10. American Heart Association. Destaques da American Heart Association 2015 : atualização das diretrizesde RCP e ACE[Internet]. 2015 [cited 2016 Mar 30];(0283):10:15 Available from: https://eccguidelines.heart.org/wp-content/uploads/2015/10/2015-AHAGuidelines-Highlights-Portuguese.pdf

11. Brasil. Ministério da Saúde. Portaria nº. 123, de 28 de fevereiro de 2005. Altera a redação do Art. $7^{\circ}$ da Portaria SAS/MS n. 210 , de 15 de junho de 2004. Diário Oficial da União, Brasília, $1^{\circ}$ mar. 2005; Seção

12. Brasil. Conselho Federal de Enfermagem. Resolução n 293/04, estabelece parâmetros para dimensionamento do quadro de profissionais de enfermagem nas instituições de saúde. In: Conselho Regional de Enfermagem. Documentos básicos de enfermagem: enfermeiros, técnicos e auxiliares. São Paulo, 2004.

13. Brasil. Conselho Federal de Enfermagem. Lei n 7.498/86. Dispõe sobre regulamentação do exercício da enfermagem e dá outras providências. São Paulo, 1986

14. Sociedade Brasileira de Cardiologia. Diretriz de ressuscitação cardiopulmonar e cuidados cardiovasculares de emergência Arq Bras Cardiol[Internet]. 2013[cited 2015 Oct 21];(100):05-113. Available from: http://publicacoes.cardiol.br/consenso/2013/ Diretriz_Emergencia.pdf

15. American Heart Association. Destaques da American Heart Association 2015: atualização das diretrizes de RCP e ACE[Internet]. 2015[cited 2015 Oct 21];(0283)10:15 Available from: https://eccguidelines.heart.org/wp-content/uploads/2015/10/2015-AHAGuidelines-Highlights-Portuguese.pdf

16. Santo F. Tempo estímulo-resposta do profissional de saúde na predisposição a fadiga de alarmes de ventiladores mecânicos: Implicações para a segurança do paciente. [Dissertação]. Universidade Federal do Estado do Rio de Janeiro. Rio de Janeiro: 2013.

17. Monteiro JLS. Tempo estímulo-resposta aos alarmes de oxímetros de pulso em unidade de cuidados intensivos neonatal: implicações para a segurança do paciente. Rio de Janeiro. [Dissertação]. Universidade Federal do Estado do Rio de Janeiro; 2012. 